DOI : $10.14746 /$ rie.2014.8.4

Warszawa

\title{
Efektywność ról międzynarodowych Unii Europejskiej
}

Unia Europejska odgrywa na arenie międzynarodowej wiele ról, wśród których najczęściej wymienia się: mocarstwo cywilne, mocarstwo normatywne, mocarstwo strukturalne, lider zrównoważonego rozwoju, wzorzec pomyślnej i kompleksowej integracji, największy udziałowiec w handlu światowym, dostarczyciel największej pomocy rozwojowej, donator największej pomocy humanitarnej, aktywny aktor dyplomatyczny, stabilizator pokoju i bezpieczeństwa międzynarodowego, atrakcyjny ośrodek cywilizacyjny i promotor wartości kultury europejskiej, „tradycyjne mocarstwo” o regionalnym zasięgu działania, ,stabilizator otoczenia”, mocarstwo neośredniowieczne globalny interwent, regionalny pacyfikator, mediator w konfliktach, lider światowej gospodarki (Zięba, 2012). Role te UE odgrywa wobec różnych regionów świata, starając się być aktorem globalnym.

Powstaje jednak pytanie, czy są one przez Unię Europejską odgrywane efektywnie? W celu odpowiedzi na to pytanie w pierwszej części artykułu zostaną omówione teoretyczne aspekty kategorii „efektywność ról międzynarodowych”, a następnie zostanie dokonana analiza efektywności ról międzynarodowych Unii Europejskiej na przykładzie jej oddziaływań w regionie śródziemnomorskim.

\section{Efektywność ról międzynarodowych - aspekty teoretyczne}

„Role międzynarodowe” są kategorią nauk społecznych. W latach 70. XX wieku, czerpiąc z wyników badań prowadzonych w psychologii i socjologii politolodzy zaczęli badać role uczestników stosunków międzynarodowych. Wśród pierwszych badaczy tej kategorii znaleźli się: Kalevi Holsti (Holsti, 1970), Carl W. Backman (Backman, 1970), Naomi B. Wish (Wish, 1980), Christer Jönsson i Ulf Westerlund (Jönsson, Westerlund, 1982). W latach 80. problematykę tę podjęli także: Stephen Walker oraz jego zespół - James Rosenau, Margaret G. Hermann, Charles F. Hermann, Sheldon W. Simon, Eric G. Singer, Valerie M. Hudson, a efektem ich pracy była książka pt. Role Theory and Foreign Policy Analysis, opublikowana w 1987 roku (Walker, 1987). W nauce polskiej badania nad teorią ról międzynarodowych rozpoczął Ziemowit Jacek Pietraś (Pietraś, 1989). W latach 90. kategoria ról międzynarodowych zyskała większe zainteresowanie, a wśród najbardziej znanych prac na ten temat znalazły się pozycje m.in.: Lisbeth Aggestam, Marijke Breuning, Sebastiana Harnischa, Hannsa Maulla, Cornelie Frank, Cristiana Cantira, Juliet Kaarbo, Camerona G. Thiesa (Aggestam, 1999; Brauning, 2011; Cantir, Kaabo, 2012; Thies, 2010; Harnisch, Frank, Maull, 2011). 
Dokonując analizy dotychczasowych badań „role międzynarodowe” możemy zdefiniować jako system działań i oddziaływań uczestnika stosunków międzynarodowych, determinowany głównie jego międzynarodową pozycją oraz tożsamością (Zając, 2015, s. 135). Pozycja, czyli miejsce jakie podmiot zajmuje w systemie stosunków międzynarodowych niewątpliwie wpływa na jego koncepcję roli oraz możliwość jej implementacji. Od niej też zależy to, jakie role będą uczestnikowi narzucane z zewnątrz bądź oczekiwane przez innych uczestników stosunków międzynarodowych. Pozycja międzynarodowa jest również czynnikiem determinującym intensywność odgrywanych przez niego ról, czyli częstotliwość ich występowania. Drugim istotnym determinantem ról międzynarodowych poszczególnych aktorów jest ich tożsamość, rozumiana jako „tożsamość wewnętrzna”, stanowiąca o spójności części składowych podmiotu oraz „tożsamość zewnętrzna”, która oznacza jego odrębność na tle innych. Elementami, które warunkują tożsamość uczestnika stosunków międzynarodowych są przede wszystkim czynniki historyczne i kulturowe, przestrzenne, geograficzne, ekonomiczne, wojskowe, ideologiczne, psychologiczne (Kukułka, 1999, s. 11-15). Od nich zależy poczucie „kim jestem” i ,jak mnie postrzegają inni”.

Każdy uczestnik stosunków międzynarodowych może odgrywać jednocześnie wiele ról, klasyfikowanych według różnych kryteriów: podmiotowego, przedmiotowego, przestrzennego czasu czy hierarchiczności, a dla oceny działań i oddziaływań danego uczestnika stosunków międzynarodowych posługujemy się kategorią efektywności ról międzynarodowych. Należy podkreślić jednak, iż nie wszystkie role dany uczestnik odgrywa w sposób świadomy i celowy, więc pojęcie „efektywność” będzie odnosić się jedynie do tych ról międzynarodowych, które aktor podejmuje w sposób zamierzony i celowy.

„Efektywność ról międzynarodowych” będziemy rozumieli zatem jako skuteczność realizacji wytyczonego celu przy uwzględnieniu nakładów (kosztów). Jednak w przypadku ról międzynarodowych trudno mierzalne są koszty, bowiem nie jest uzasadnione ograniczanie ich jedynie do ponoszonych nakładów finansowych. Istotne są bowiem również koszty niematerialne, a te są niezwykle trudne do zmierzenia. Ponadto, w świecie istniejących powiązań i współzależności ten sam cel może być realizowany przez wiele podmiotów. Trudno więc dokładnie stwierdzić, na ile urzeczywistnianie wytyczonych zamierzeń jest efektem działań podejmowanych przez jednego aktora międzynarodowego, a na ile jest to wypadkowa wielu różnorodnych czynników. Niemniej oceny efektywności ról międzynarodowych danego aktora możemy dokonać przez pryzmat trzech czynników: 1) racjonalności przyjętej przez niego koncepcji - role deklarowane; 2) umiejętności i konsekwencji w jej realizowaniu, czyli stopnia jej realizacji - role rzeczywiste; 3) poziomu aprobaty roli przez innych aktorów stosunków międzynarodowych, a zwłaszcza przez jej adresatów - role oczekiwane.

Racjonalność jest pierwotną kategorią w stosunku do efektywności, innymi słowy efektywność jest funkcjonalnym aspektem racjonalności (Sadowski, 1995, s. 103). Racjonalna koncepcja roli powinna uwzględniać zarówno własne możliwości aktora, jak i okoliczności, w których działa. Racjonalna ocena własnych możliwości powinna opierać się na właściwej ocenie własnej pozycji, czyli też realnego oszacowania posiadanego potencjału, a także zdolności jego wykorzystania. Ważny jest również odpowiedni dobór środków i metod, który zależy nie tylko od szeroko pojętego potencjału 
aktora, lecz także od poziomu racjonalności w jego procesie decyzyjnym. Zgodnie z założeniami teorii racjonalnego wyboru jednostki cechuje wystarczająca racjonalność, by wybrać najlepszy sposób działania, niezależnie od tego z jak bardzo złożoną sytuacją mają do czynienia. Efektywny proces decyzyjny to taki, który pozwala na wyselekcjonowanie najbardziej skutecznych środków pozwalających na osiagnięcie pozytywnie wartościowanych celów. Zwolennicy teorii racjonalnego wyboru zakładaja, że decyzje podejmowane są w warunkach pełnej informacji, a racjonalne działanie decydenta opiera się na realnej ocenie sytuacji, a nie na założeniach. W przypadku stosunków międzynarodowych oznacza to konieczność posiadania wiedzy o uwarunkowaniach wewnętrznych danego podmiotu i uwarunkowaniach międzynarodowych, głównie o celach, działaniach i możliwościach oddziaływania innych aktorów międzynarodowych oraz istoty systemu międzynarodowego.

Dla efektywności roli międzynarodowej istotne znaczenie ma również stopień aprobaty roli aktora przez społeczność międzynarodową, a zwłaszcza przez jej adresatów, a więc poziom zbieżności między rolą wybierana/deklarowaną a oczekiwaną/narzucaną. Czynnikami wpływającymi na efektywność ról międzynarodowych są również zmiany zachodzące w systemie międzynarodowym. Pogłębiająca się internacjonalizacja prowadząca do procesów globalizacji i w konsekwencji do rosnących współzależności wymusza na podmiotach międzynarodowych większą otwartość na czynniki zewnętrzne i uwzględnianie ich w procesie przyjmowania i odgrywania konkretnych ról międzynarodowych. Rosnąca sieć współpracy i współzależności w stosunkach międzynarodowych powoduje, że aprobata społeczności międzynarodowej dla deklarowanej i odgrywanej przez aktora roli ma niezwykle ważne znaczenie dla jej efektywności. W przypadku jej braku poziom efektywności takiej roli może być niewielki.

Efektywność ról międzynarodowych mierzy się dopiero po upływie pewnego czasu, w którym rola została zadeklarowana lub rozpoczął się proces jej realizacji. Stąd efekt ról krótkoterminowych realizacji będzie bardziej widoczny niż w przypadku ról średnio- i długoterminowych. Nie bez znaczenia jest również współzależność efektywności poszczególnych ról. Efektywność jednego rodzaju ról ma wpływ na efektywność pozostałych, gdyż pociąga za sobą przeświadczenie, że aktor odgrywający daną rolę ma możliwości efektywnego działania. Wzmocni to jego pozycję międzynarodową, a w konsekwencji ułatwi, w mniejszym lub większym stopniu, realizację innych jego ról. Największą efektywność osiaga się wówczas, gdy role deklarowane, rzeczywiste i oczekiwane są kompatybilne. W sytuacji, gdy między dwoma lub/i trzema z tych ról dochodzi do konfliktu efektywność ich jest ograniczona.

\section{Efektywność ról międzynarodowych UE na przykładzie jej oddziaływań w regionie śródziemnomorskim}

Region śródziemnomorski sąsiadujący z Unią Europejską stanowi jeden z priorytetowych kierunków w jej polityce zewnętrznej, stąd od połowy lat 90 . XX wieku stara się ona odgrywać jednocześnie kilka ról wobec państw w nim położonych. Najważniejszymi z nich są role: aktywnego aktora w rozwiązywaniu konfliktu arabsko-izraelskiego; promotora środków budowy zaufania, partnerstwa, bezpieczeństwa i rozbrojenia; 
promotora reform rynkowych i zrównoważonego rozwoju; propagatora demokracji i praw człowieka oraz dialogu międzykulturowego. Taki dobór ról jest wynikiem nie tylko interesów UE i jej państw członkowskich w tym obszarze, ale również wartości, norm i zasad, będących komponentami unijnej tożsamości międzynarodowej (Zając, 2010).

Analizowanie efektywności ról unijnych jest zadaniem niezwykle trudnym. Na sytuację w regionie śródziemnomorskim wpływa bowiem wiele determinant wewnętrznych i zewnętrznych, a oddziaływania Unii są wśród nich jednymi z wielu. Dlatego też w niniejszym artykule zostanie dokonana analiza efektywności ról Unii Europejskiej w regionie śródziemnomorskim, poprzez pryzmat trzech czynników: 1) racjonalności koncepcji UE, czyli role deklarowane; 2) stopnia jej realizacji, ze szczególnym uwzględnieniem konsekwencji i umiejętności UE w odgrywaniu zadeklarowanych ról, tj. role rzeczywiste; 3) poziomu akceptacji ról Unii przez państwa regionu, czyli role oczekiwane.

\subsection{Racjonalność koncepcji ról - role deklarowane}

Pierwsze spójne i całościowe działania wobec państw wschodniego i południowego wybrzeża Morza Śródziemnego Unia Europejska podjęła w 1995 roku. Wprawdzie już od lat 70. XX podejmowała takowe próby, ale były one ograniczone. Dopiero w listopadzie 1995 roku Unia Europejska, przeżywająca wówczas jeden z najlepszych okresów swojego rozwoju, zdecydowała się na nawiązanie wieloaspektowej współpracy z dwunastoma partnerami, położonymi na przeciwległym wybrzeżu śródziemnomorskim - Algierią, Cyprem, Egiptem, Izraelem, Jordanią, Libanem, Maltą, Marokiem, Autonomią Palestyńską, Syria, Tunezją i Turcją ${ }^{1}$ W zainicjowanym wówczas programie, nazwanym Partnerstwem Eurośródziemnomorskim (EMP) lub Procesem barcelońskim (od nazwy miejscowości, w której miała miejsce konferencja inaugurująca) przyjęto jako cel rozwijanie współpracy w trzech koszykach: 1) politycznym i bezpieczeństwa; 2) gospodarczym i finansowym; 3) społecznym, kulturowym i humanitarnym. Z punktu widzenia Unii Europejskiej taki zakres przedmiotowy był w pełni uzasadniony. $W$ regionie śródziemnomorskim występowało wiele problemów, generujących liczne wyzwania i zagrożenia dla obszaru europejskiego (m.in. nielegalne migracje, terroryzm, zagrożenia militarne, pogłębiająca się degradacja środowiska naturalnego), a ich rozwiązanie wymagało zastosowania wielu różnych środków i metod. Podejście kompleksowe obejmujące zarówno działania polityczne, gospodarcze, jak i społeczne wydawało się zatem optymalnym sposobem działania. Doświadczenia państw wysoko rozwiniętych wskazywały, że najlepszym sposobem na poprawę sytuacji państwa i społeczeństwa jest wdrożenie gospodarki wolnorynkowej, systemu demokratycznego, przy jednoczesnym rozwoju wielopłaszczyznowej współpracy między państwami i ich społeczeństwami. W tym kontekście zadeklarowanie przez Unię Europejską odgrywania wielu ról jednocześnie: aktywnego aktora w rozwiązywaniu konfliktu

${ }^{1}$ Cypr i Malta stały się członkami UE w 2004 roku. 
arabsko-izraelskiego, promotora środków budowy zaufania, partnerstwa i bezpieczeństwa oraz rozbrojenia, promotora reform rynkowych i zrównoważonego rozwoju regionu, propagatora wartości demokratycznych, praw człowieka i dialogu międzykulturowego wydawało się najlepszą strategią przekształcenia regionu śródziemnomorskiego w strefę pokoju, stabilności i dobrobytu. Było to założenie racjonalne również z punktu widzenia środków, jakimi UE dysponuje. Jako mocarstwo cywilne Unia przyjęła bowiem szereg środków o charakterze politycznym, gospodarczym i społecznym.

Zastrzeżenia budził jednak zakres podmiotowy. Partnerstwo Eurośródziemnomorskie objęło zarówno państwa arabskie, położone nad Morzem Śródziemnym, jak i Izrael. Wprawdzie program został powołany do życia w 1995 roku, a więc wówczas, gdy proces pokojowy na Bliskim Wschodzie odnosił największe sukcesy ${ }^{2}$, jednak stosunkowo szybko okazało się, że zasiadanie przy jednym stole przedstawicieli państw arabskich i Izraela okazywało się często niemożliwe. Zwłaszcza od 2000 roku, po wybuchu II Intifady problem ten wyraźnie się nasilił, wprowadzając de facto Partnerstwo Eurośródziemnomorskie w stan paraliżu.

Dostrzegając problemy współpracy eurośródziemnomorskiej i działając w nowych warunkach, po rozszerzeniu w 2004 roku, Unia Europejska uzupełniła swoją koncepcję, proklamując Europejską Politykę Sąsiedztwa. Nowa formuła nie zlikwidowała dotychczasowych form współpracy, ale została potraktowana jako inicjatywa komplementarna. W większym stopniu niż Partnerstwo Eurośródziemnomorskie położyła nacisk na rozwój stosunków dwustronnych między Unią Europejską a jej sąsiadami, co było podejściem słusznym, bowiem pozwoliło nie tylko na realizację różnych polityk wobec Izraela i państw arabskich, ale także na większe zdywersyfikowanie działań wobec krajów arabskich, które znajdowały się na różnych etapach zaawansowania we współpracy z UE. Już jednak utworzona w 2008 roku Unia dla Środziemnomorza okazała się mało trafionym pomysłem. Oprócz państw - uczestników EMP została ona rozszerzona o państwa bałkańskie, Mauretanię i Monako, co faktycznie ją rozmyło i uczyniło współpracę eurośródziemnomorską jeszcze trudniejszą. W efekcie Unia dla Środziemnomorza jest instytucją o słabej skuteczności działania.

Również koncepcja działania Unii Europejskiej wobec wydarzeń Arabskiej Wiosny pozostaje dyskusyjna. Wiosną 2011 roku Unia podjęła tradycyjne dla siebie działania określane mianem 3M - Money, Mobility, Markets, jednak w przypadku większości państw arabskich, w których doszło do społecznych rewolucji podejście to okazało się mało skuteczne (Przybylska-Maszner, 2011; Völkel, 2014; Zając, 2012). UE okazała

2 W 1993 roku dokonał się wyraźny przełom w stosunkach izraelsko-palestyńskich; Izrael uznał Organizację Wyzwolenia Palestyny za reprezentanta narodu palestyńskiego, a OWP uznała istnienie Państwa Izraela, zaczęto tworzyć zalążki przyszłego niepodległego państwa palestyńskiego, a między oboma podmiotami rozpoczęła się normalizacja stosunków. W 1994 roku został podpisany traktat pokojowy między Izraelem a Jordanią. Toczyły się również negocjacje pokojowe między Izraelem a Syrią i Libanem. W tej sytuacji uruchomienie przez Unię Europejską programu wielostronnej współpracy, do której włączono Izrael i państwa arabskie wydawało się zabiegiem logicznym i uzasadnionym. Unia uznała, że podpisanie porozumień pokojowych na najwyższym szczeblu umożliwi rozpoczęcie procesu budowy pokoju na różnych poziomach (międzyrządowym i pozarządowym) i w różnych dziedzinach (polityki, gospodarki, kultury itd.). Temu celowi miało służyć Partnerstwo Eurośródziemnomorskie. 
się także bezsilna w przypadku eskalacji konfliktów w Libii i Syrii. W Libii interwencję zbrojną, wiosną 2011 roku, podjęło NATO (choć w perspektywie średnioterminowej mało skuteczna). W Syrii natomiast od końca września 2014 roku trwają naloty poszczególnych państw na pozycje Państwa Islamskiego (ISIL - Islamic State of Iraq and the Lewant) ${ }^{3}$.

\subsection{Stopień realizacji przez UE koncepcji ról: role rzeczywiste}

Z perspektywy niemal dwudziestu lat funkcjonowania zinstytucjonalizowanej współpracy eurośródziemnomorskiej (licząc od utworzenia w 1995 roku Partnerstwa Europśródziemnomorskiego) należy stwierdzić, iż stopień realizacji przyjętych przez UE ról w tym regionie jest bardzo niski. W początkach 2015 roku rozwój sytuacji w tym regionie staje się coraz bardziej nieprzewidywalny. Arabska wiosna, która rozpoczęła się na przełomie lat 2010/2011 objęła swoim zasięgiem kolejne państwa południowo- i wschodniośródziemnomorskie: Egipt stanął na skraju wojny domowej między silną armią a zwolennikami Bractwa Muzułmańskiego; w Syrii nastąpiła eskalacja konfliktu zbrojnego; rozwój wydarzeń w Libii nadal jest niepewny, konflikt arabsko-izraelski pozostaje nierozwiązany. Dodatkowo komplikuje się sytuacja w obszarach sąsiednich. Radykalizuje się część ugrupowań islamskich na Półwyspie Arabskim i w Afryce, co powoduje wzrost terroryzmu islamskiego oraz intensyfikację konfliktów. Irak jest państwem silnie zdestabilizowanym, i podobnie jak w Syrii i Libanie, na jego obszarze działa silnie radykalne Państwo Islamskie (ISIL), a między państwami Zatoki Perskiej i Iranem nasila się rywalizacja o wpływy w regionie.

Sytuacja ta jest oczywiście wynikiem wielu czynników, niemniej należy zauważyć, że między rolami deklarowanymi przez UE a realizowanymi istniała wyraźna sprzeczność. Działania Unii Europejskiej były bowiem niekonsekwentne i niespójne we wszystkich trzech koszykach Partnerstwa Eurośródziemnomorskiego. Pomimo głoszenia haseł demokratyzacji i wprowadzania rządów prawa w państwach partnerskich, przez wiele lat Unia Europejska tolerowała autorytarne rządy arabskie. Udzielała im wsparcia politycznego, mimo iż raporty Komisji Europejskiej z 1999 roku oraz 2009 roku wyraźnie rysowały obraz łamania przez nie zasad demokratycznych (Pace, Seeberg, 2010). Wprawdzie UE zainicjowała i wsparła finansowo programy na rzecz usprawnienia działalności administracji publicznej, decentralizacji władzy, promowania praw kobiet i zwiększenia udziału ugrupowań pozarządowych w kształtowaniu polityki państwa (Zając, 2010, s. 211-228), jednak podejmowała takie formy pomocy, które nie wywoływały zaniepokojenia władz państw arabskich (Youngs, 2006). Działania UE były także niespójne; Bruksela nie uznała legitymacji rządu Hamasu wyłonionego w 2006 roku w wyborach w Autonomii Palestyńskiej, które jej przedstawiciele uznali

3 W drugiej połowie września 2014 roku Francja, USA wspomagane przez państwa arabskie - Bahrajn, Arabię Saudyjską, Jordanię, Zjednoczone Emiraty Arabskie oraz Katar rozpoczęły naloty na bojowników Państwa Islamskiego w Iraku i Syrii. Działania te są podejmowane bez mandatu Rady Bezpieczeństwa ONZ, co wywołuje krytykę ze strony Rosji, będącej stałym członkiem tej Rady. 
uprzednio za spełniające standardy demokratyczne. Niekonsekwentnie Unia Europejska stosowała również politykę warunkowości, zapisaną w rozporząadzeniu MEDA, układach stowarzyszeniowych i planach działania, podpisywanych w ramach Europejskiej Polityki Sąsiedztwa (ENP).

Dychotomia polityki UE była również widoczna w zakresie współpracy gospodarczej. Jednym ze sztandarowych celów przyjętych w Deklaracji barcelońskiej było utworzenie do 2010 roku eurośródziemnomorskiej strefy wolnego handlu i tym samym poprawa sytuacji społeczno-gospodarczej państw partnerskich oraz doprowadzanie do zrównoważonego rozwoju regionu. Unia Europejska podjęła wprawdzie działania na rzecz przyspieszenia transformacji gospodarczej państw arabskich i utworzyła programy na rzecz zrównoważonego rozwoju regionu ${ }^{4}$, ale jednocześnie konsekwentnie sprzeciwiała się włączeniu do strefy wolnego handlu artykułów rolnych oraz rybnych, stanowiących znaczącą część dóbr wytwarzanych przez państwa arabskie. Dopiero po kilku latach zaczęła stopniowo zmieniać swoje stanowisko, jednak bez znoszenia barier pozataryfowych, wprowadzenia swobodnego przepływu ludzi, większej liberalizacji sektora usług czy ustanowienia systemu gwarancji dla przedsiębiorstw europejskich inwestujących w krajach arabskich, o co te postulowały. Ponadto, pomimo wysokiego miejsca, jakie Unia Europejska zajmowała wśród inwestorów zagranicznych w państwach Afryki Północnej i Bliskiego Wschodu, inwestycje te pod koniec pierwszej dekady XXI w. zajmowały mniej niż $1 \%$ ogółu inwestycji unijnych w państwach rozwijających się (Bremberg, Driss, Horst, Soler Lecha, Werenfels, 2009). W efekcie, sytuacja gospodarczo-społeczna państw południowego i wschodniego wybrzeża Morza Śródziemnego nie poprawiła się, co stało się jednym z powodów wybuchu pod koniec 2010 roku Arabskiej Wiosny.

Unia Europejska głosiła również hasła dialogu międzykulturowego, w celu przezwyciężania stereotypów, zwalczania rasizmu, ksenofobii, antysemityzmu, islamofobii i budowania pozytywnych relacji między społeczeństwami państw europejskich, północnoafrykańskich i bliskowschodnich. Jednak działania w tym zakresie były znacznie bardziej realistyczne aniżeli deklaracje. Obawiając się napływu nielegalnych imigrantów, Unia nie otworzyła swoich granic dla obywateli śródziemnomorskich krajów arabskich, co wywoływało dużą krytykę ze strony ich władz i rozczarowanie tamtejszych społeczeństw.

2.3. Poziom akceptacji ról UE przez śródziemnomorskie państwa partnerskie: role oczekiwane

Role Unii Europejskiej nigdy nie były w pełni akceptowane przez państwa wschodniego i południowego wybrzeża Morza Śródziemnego. Nawet jeśli aprobowane były

4 W 1997 r. program działań na rzecz ochrony środowiska naturalnego - SMAP, w 2005 r. program redukcji największych źródeł zanieczyszczeń „Horyzont 2020”, w 2003 r. projekt rozwoju sieci transportowej w regionie śródziemnomorskim (Eurośródziemnomorski Regionalny Plan Działania w Dziedzinie Transportu RTAP) oraz plan rozwoju współpracy energetycznej, w 2007 r. - Eurośródziemnomorskie Partnerstwo Energetyczne. 
niektóre z ról deklarowanych, to sposób ich realizacji przez Unię Europejską wywoływał krytykę i w konsekwencji ograniczony stopień aprobaty.

Pierwszy koszyk współpracy dotyczący bezpieczeństwa objął jego tzw. miękkie aspekty, czyli bezpieczeństwo pozamilitarne oraz metody zapobiegania i prewencji. Z punktu widzenia państw partnerskich był to błąd. Trwający od kilkudziesięciu lat konflikt arabsko-izraelski sprawia bowiem, że dla nich znacznie większe znaczenie mają tradycyjne metody zapewniania bezpieczeństwa, oparte na sile militarnej. Ponadto - argumentowano - nie można koncentrować się na środkach budowy zaufania w sytuacji nierozwiązanych problemów. Wprawdzie UE jednocześnie przyjęła rolę aktywnego aktora w rozwiązywaniu konfliktu arabsko-izraelskiego, ale jej skuteczność oddziaływania była w tym względzie mocno ograniczona. Różne stanowiska państw arabskich i Izraela w kwestii rozwiązania konfliktu na Bliskim Wschodzie wpływają na ich stosunek do Unii Europejskiej jako aktora działającego na rzecz jego zakończenia. Akceptacja stanowiska UE jest znaczenie większa wśród krajów arabskich, aniżeli w Izraelu. Jednak pomimo akceptacji koncepcji UE w rozwiązywaniu konfliktu arabsko-izraelskiego, przedstawiciele państw arabskich wyraźnie wykazywali niezadowolenie z jej realizacji. Niejednokrotnie wzywali Unię do odgrywania bardziej zdecydowanej roli i wyrażali nadzieję, że stanie się ona uczciwym mediatorem (honest broker) w konflikcie arabsko-izraelskim. Krytyczną ocenę działań UE ze strony krajów arabskich wzmaga jej stanowisko wobec polityki Izraela. Unia potępia wprawdzie Izrael za osadnictwo na terytoriach okupowanych i za budowę muru, uznając je za niezgodne z prawem międzynarodowym, ale nie idą za tym żadne konkretne działania; ograniczają się one jedynie do retoryki. Dodatkowo, wobec wszystkich umów z Unią Europejską Izrael przyjmuje interpretację, że integralną częścią jego terytorium są ziemie zajęte podczas wojny sześciodniowej 1967 roku. W opinii państw arabskich brak reakcji UE oznacza zgodę na taką interpretację (Pioppi, Tocci, Karam, 2006, s. 31). Dopiero w połowie 2013 roku, w obliczu wyraźnej destabilizacji w regionie bliskowschodnim oraz przedsięwzięciach amerykańskich na rzecz reaktywowania izraelsko-palestyńskiego procesu pokojowego, Komisja Europejska wysłała do państw członkowskich zalecenia nieudzielania pomocy finansowej organizacjom izraelskim działającym na terytoriach zajętych przez Izrael w wojnie sześciodniowej. Jednocześnie w kwietniu 2013 roku szefowie dyplomacji 13 państw UE, wśród nich Francji, Wielkiej Brytanii i Hiszpanii wystosowali list do Wysokiej Przedstawiciel Unii do Spraw Zagranicznych i Polityki Bezpieczeństwa Catherine Ashton, w którym postulowali wprowadzenie przez UE zasady zobowiązującej izraelskie firmy, działające na obszarach zajętych podczas wojny z 1967 roku, do zamieszczania etykiety informującej, że eksportowane przez nich produkty zostały wytworzone na terytoriach okupowanych.

Podejrzliwość Arabów, zwłaszcza Palestyńczyków, wobec Unii Europejskiej wzmogło szybkie wycofanie przez nią poparcia dla rządu Hamasu, utworzonego w 2006 roku. Rząd ten został wyłoniony w wyniku powszechnych demokratycznych wyborów, więc posunięcie Unii Europejskiej miało charakter wyłącznie polityczny, a nie prawny. Postawiło to pod znakiem zapytania sens deklaracji unijnych o działaniach na rzecz demokratyzacji Autonomii Palestyńskiej. Niekonsekwentne postępowanie Unii Europejskiej sprawia, że w państwach arabskich ma ona opinię aktora niewiarygodnego i nieskutecznego, któremu brakuje koherentnej polityki. W konsekwencji jest postrze- 
gana nie jako podmiot samodzielny, ale wspomagający Stany Zjednoczone, które posiadają realne możliwości oddziaływania. W opinii państw arabskich USA występują w roli ,złego policjanta”, a UE stara się odgrywać rolę „,dobrego policjanta” (Sayigh, 2007). Niewiarygodność Unii Europejskiej w oczach Arabów wzmacniają konotacje historyczne, a także brak wiary w jej realne możliwości działania, wynikające z jej specyfiki jako aktora międzynarodowego ${ }^{5}$ (Makdisi, Göksel, Hauck, Reigeluth, 2009; Boris, 2014). Również w oczach wielu Żydów Unia Europejska nie odgrywa właściwej roli w rozwiązywaniu konfliktu. Wprawdzie decydenci izraelscy pozytywnie wypowiadają się o działaniach UE na Bliskim Wschodzie, ale też nierzadko artykułowali słowa ostrej krytyki i oskarżenia o zachowania stronnicze.

Podejrzliwość państw arabskich budziła również polityka Unii Europejskiej w zakresie wprowadzenia w regionie Bliskiego Wschodu strefy wolnej od broni masowego rażenia. Choć oczekiwania państw arabskich w tym względzie były zgodne z deklaracjami UE, to krytykę wywoływały jej działania. Zarzucały one Unii, że koncentruje się na kwestii nierozprzestrzeniania broni masowego rażenia, przy jednoczesnym braku działań na rzecz rzeczywistego rozbrojenia, co jest niekorzystne w sytuacji braku równowagi strategicznej w regionie. Jednym państwem na Bliskim Wschodzie posiadającym broń jądrową jest bowiem Izrael, który dodatkowo nie jest sygnatariuszem Układu o Nieproliferacji (NPT). Ponadto, krytykę państw arabskich wzmacnia promowanie przez UE rozbrojenia i ograniczenia zbrojeń na poziomie horyzontalnym, obejmującym jedynie państwa południowego i wschodniego wybrzeża Morza Śródziemnego, a nie wspomina ona o poziomie wertykalnym, który uwzględniłby także państwa unijne.

Również koncepcja roli propagatora wartości demokratycznych i praw człowieka wywoływała dystans państw arabskich. Promowanie przez Unię idei, że islam jest przeszkodą $\mathrm{w}$ modernizacji społeczeństw państw muzułmańskich rodził wrażenie, iż Europa Zachodnia traktuje świat arabski i muzułmański jako zacofany, niecywilizowany, a percepcja ta była umacniana przez doświadczenia historyczne. W krajach arabskich wracano pamięcią do czasów, kiedy były koloniami lub protektoratami państw europejskich, a nawet okresu wypraw krzyżowych. Jak pisał Amin Maalouf ,arabski Wschód nadal widzi w Zachodzie swego naturalnego wroga" (Maalouf, 2001, s. 282). Ponadto podejście Unii Europejskiej świadczyło o ignorowaniu odmienności kulturowej państw partnerskich. Wprawdzie nie ma podstaw, aby twierdzić, że islam i system demokratyczny są niekompatybilne, a wielu intelektualistów arabskich nie widzi żadnych przeszkód w połączeniu ustroju demokratycznego z religią muzułmańską (Esposito, 1991; Krämer, 1993; Abdellatif, 2004), to jednak jak ujął to Janusz Danecki: „Nowoczesne państwo narodowe Zachodu cechuje suwerenność wewnętrzna, związana $\mathrm{z}$ demokracją oraz suwerenność zewnętrzna. $\mathrm{Z}$ żadną z tych cech nie mamy do czynienia w państwach arabskich, czy ogólniej muzułmańskich. Samo pojęcie suwerenności z muzułmańskiego punktu widzenia jest czymś niezrozumiałym. Suwerenność państwa, narodu, grupy czy jednostki oznacza całkowitą niezależność. To w islamie jest

5 Na przykład, gdy latem 2006 roku, w czasie wojny między Izraelem a Hezbollahem, Hiszpania zaproponowała rozmieszczenie na granicy libańsko-syryjskiej cywilnej misji unijnej Syria i Hezbollah pomysł ten zdecydowanie odrzuciły, uznając, że Europejska Polityka Bezpieczeństwa i Obrony jest niewystarczająco rozwinięta, a UE nie jest gotowa do podjęcia takiej operacji. 
nie do pomyślenia, albowiem Bóg określa wszystko, w tym suwerenność narodu i jednostki. [...] Nie istnieje suwerenność wewnętrzna obywateli, a co za tym idzie brak jest demokracji. [...] Wzorce, jakie propaguje [Zachód - przyp. J.Z.] są nazbyt odległe od muzułmańskich tradycji. Dotyczy to na przykład rodziny, roli kobiet, miejsca wiary w życiu człowieka" (Danecki, 2001, s. 371, 383-385).

Wątpliwość państw arabskich budziła również przyjęta koncepcja działania w ramach drugiego koszyka. Tworzenie eurośródziemnomorskiej strefy wolnego handlu było skoncentrowane na produktach przemysłowych, z wykluczeniem towarów rolnych, rybnych oraz usług, stanowiących największą część dochodów państw arabskich (Zaim, 1999; Minasi, 1998). Dopiero po kilku latach od ustanowienia Partnerstwa Eurośródziemnomorskiego produkty te zostały, częściowo uwzględnione, co jednak nie zmieniło zasadniczo sytuacji gospodarczo-społecznej krajów arabskich. Ponadto, Unia Europejska pominęła w programach wobec regionu śródziemnomorskiego kwestię zadłużenia zagranicznego, pozostawiając je do rozwiązania przez inne instytucje międzynarodowe, co wpływało negatywnie na proces reformowania gospodarek krajów partnerskich.

Również założenia współpracy w trzecim koszyku nie pozostawały bez zastrzeżeń ze strony krajów arabskich. W opinii decydentów państw arabskich nie można mówić o dialogu międzykulturowym bez swobodnych kontaktów międzyludzkich, a takowe utrudniały reżimy wizowe utrzymywane przez państwa unijne względem krajów arabskich. Dialog międzykulturowy nie może ograniczać się tylko do współpracy ekspertów czy do organizowania wystaw, musi odbywać się bowiem we wzajemnym poszanowaniem różnic kulturowych. Za utrudniający rozwój dialogu międzykulturowego uważano również wzrost, w ostatnich latach, w państwach członkowskich Unii Europejskiej islamofobii i ksenofobii.

\section{Podsumowanie}

Unia Europejska jest specyficznym aktorem stosunków międzynarodowych, a prowadzona przez nią polityka zagraniczna jest kompromisem wypracowanym pomiędzy jej państwami członkowskimi. Od momentu utworzenia, na podstawie Traktatu z Maastricht, Wspólna Polityka Zagraniczna i Bezpieczeństwa ma charakter współpracy międzyrządowej (Zięba, 2014). Ze względu na różne interesy kraje członkowskie są w stanie zgodzić się, co do ogólnych wytycznych działania, ale w praktyce ich realizacja jest znacznie trudniejsza. $\mathrm{W}$ ten sposób dochodzi do konfliktu między rolami deklarowanymi przez Unię Europejską a jej rolami rzeczywistymi.

Widać to wyraźnie na przykładzie polityki Unii Europejskiej w regionie śródziemnomorskim. Unia głosiła hasła promowania demokracji, ale przez wiele lat wspierała autorytarne reżimy arabskie, ponieważ współpracowały one w zwalczaniu islamskiego ekstremizmu i terroryzmu oraz zapobieganiu nielegalnym imigracjom, co było szczególnie ważne dla Francji, Hiszpanii i Włoch. Unia deklarowała działania na rzecz poprawy sytuacji ekonomicznej śródziemnomorskich krajów arabskich, ale niechętnie włączała do tworzonej strefy wolnego handlu artykuły rolne i rybne, których eksport stanowi dużą część dochodów tych państw, ponieważ Francja, Hiszpania i Włochy chroniły 
własne gospodarki. UE propagowała rozwijanie dialogu międzykulturowego, ale jednocześnie, obawiając się fali nielegalnych imigrantów, utrzymywała zamknięte granice dla mieszkańców państw partnerskich, a państwa unijne wprowadzały wobec imigrantów restrykcyjne przepisy (Zając, 2014).

Do konfliktu dochodziło również między rolami deklarowanymi i rzeczywistymi a rolami oczekiwanymi. W przypadku polityki śródziemnomorskiej arabskie państwa partnerskie UE nie zgadzały się z eksponowaniem przez nią miękkich aspektów bezpieczeństwa, przy pomijaniu aspektów tradycyjnych, kraje arabskie niejednokrotnie apelowały o otwarcie rynku unijnego dla swoich produktów rolnych i rybnych i czuły się traktowane nierównoprawnie w kwestiach społeczno-kulturowych. Zastrzeżenia te potęgowało niekonsekwentne zachowanie Unii Europejskiej, będące wynikiem konfliktu między rolami deklarowanymi a rolami rzeczywistymi. W konsekwencji konflikt między rolami deklarowanymi, rzeczywistymi i oczekiwanymi implikuje małą efektywność ról Unii Europejskiej w regionie śródziemnomorskim.

Niniejszy artykuł został ograniczony do analizy przypadku, jednak wnioski, dotyczące konfliktu unijnych ról deklarowanych, odgrywanych oraz oczekiwanych wobec UE, jakie się z niej nasuwają są w dużej mierze adekwatne do oddziaływań UE wobec innych regionów świata.

\section{Bibliografia}

Abdellatif A. M. (2004), Human Rights in the Arab Mediterranean Countries: Intellectual Discourse. Socio-Economic Background and Legal Instruments, „Mediterranean Politics”, vol. 9, nr 3.

Aggestam L. (1999), Role Conceptions and the Politic of Identity in Foreign Policy, „ARENA Working Papers", WP 99/8.

Backman C. W. (1970), Role Theory ad International Relations: A Commentary and Extension, „International Studies Quarterly", vol. 14, nr 3, s. 310-319.

Bailin N. W. (1980), Foreign Policy Makers and National Role Conceptions, „International Studies Quarterly, nr 4, vol. 24.

Bouris D. (2014), The European Union and Occupied Palestinian Territories. State-building without a state, Routledge, London-New York.

Bremberg N., Driss A., Horst J., Soler Lecha E., Werenfels I. (2009), Flexible Multilateralism: Unlimited Opportunities? The Case of Civil Protection in the Mediterranean Isabelle, „EuroMeSCo Paper", nr 80.

Breuning M. (2011), Role research: genesis and blind spots, w: Role Theory in International Relations. Approaches and analyses, red. S Harnisch, C. Frank, H. W. Maull, Routledge, London-New York.

Cantir C., Kaarbo J. (2012), Contested Roles and Domestic Politics: Reflections on Role Theory in Foreign Policy Analysis and IR Theory, „Foreign Policy Analysis”, vol. 8.

Danecki J. (2001), Arabowie, Państwowy Instytut Wydawniczy, Warszawa.

Esposito J. L. (1991), Democratisation and Islam, „Middle East Journal”, vol. 45, nr 3.

Harnisch S., Frank C., Maull H. W. (red.) (2011), Role Theory in International Relations. Approaches and analyses, Routledge, London-New York.

Holsti K. (1970), National Role Conception In the Study of Foreign Policy, „International Studies Quarterly", vol. 14, nr 3. 
Jönsson Ch., Westerlund U. (1982), Role Theory in Foreign Policy Analysis, w: Cognitive Dynamics and International Politics, red. Ch. Jönsson, St. Martin Press, New York.

Krämer G. (1993), Islamist Notions of Democracy, „Middle East Report”, vol. 23, nr 4.

Kukułka J. (1999), Pojmowanie i istota tożsamości narodowej pod koniec XX wieku, w: Nowa tożsamość Niemiec i Rosji w stosunkach międzynarodowych, red. S. Bieleń, W. Góralski, Wydawnictwo Naukowe Scholar, Warszawa.

Maalouf A. (2001), Wyprawy krzyżowe w oczach Arabów, Czytelnik, Warszawa.

Makdisi K., Göksel T., Hauck H. B., Reigeluth S. (2009), UNIFIL II: Emerging and Evolving European Engagement in Lebanon and the Middle East, „EuroMeSCo Paper”, nr 76.

Minasi N. (1998), The Euro-Mediterranean Free Trade Area and its Impact on the Economies Involved, „Jean Monnet Working Paper”, nr 16, Department of Political Studies, University of Catania.

Pace M., Seeberg P. (red.) (2010), European Union's Democratization Agenda in the Mediterranean, Routledge, New York.

Pietraś Z. J. (1989), Pojęcie i klasyfikacja ról międzynarodowych, UMCS, Międzyuczelniany Instytut Nauk Politycznych, Centralny Program Badań Podstawowych 11.10.2.2.1, Lublin.

Pioppi D., Tocci N., Karam K. (2006), Domestic Politics and Conflict in the Casus of Israel, Palestine and Lebanon, „EuroMeSCo Paper”, nr 53.

Przybylska-Maszner B. (2011), The Arab Spring as a Test of post-Lisbon Capabilities and Strategies of the European Union in North Africa, w: The Arab Spring, red. B. Przybylska-Maszner, Wydawnictwo Naukowe WNPiD UAM, Poznan.

Sadowski E. (1995), Zagadnienie racjonalności i efektywności polityki zagranicznej państwa, „Stosunki Międzynarodowe - International Relations" t. 17.

Sayigh Y. (2007), Security Sector reform in the Arab Region, Challenges to Developing an Indigenous Agenda, Arab Reform Initiative, „Thematic Papers”, nr 2.

Thies C. G. (2010), Role Theory and Foreign Policy, w: The International Studies Encyclopedia, red. R. A. Denemark, vol. X, West Sussex, UK.

Völkel J. C. (2014), More for More, Less for Less - More or Less: A Critique of the EU's Arab Spring Response à la Cinderella, „European Foreign Affairs Review”, nr 2.

Walker S. G. (red.) (1987), Role Theory and Foreign Policy Analysis, Duke University Press, Durham.

Youngs R. (2006), Europe's Flawed Approach to Arab Democracy, Centre for European Reform, London.

Zaim F. (1999), The Third Generation of Euro-Mediterranean Association Agreements: A View from the South, „Mediterranean Politics”, vol. 4, nr 2.

Zając J. (red.) (2014), Unia Europejska w regionie śródziemnomorskim: między politykq wspólnq a interesami państw członkowskich, Wydawnictwo WDiNP, Warszawa.

Zając J. (2015), Teoria ról międzynarodowych, w: Teorie i podejścia badawcze w nauce o stosunkach międzynarodowych, red. R. Zięba, S. Bieleń, J. Zając, Wydawnictwo WDiNP UW, Warszawa.

Zając J. (2010), Role Unii Europejskiej w regionie Afryki Pólnocnej i Bliskiego Wschodu, Wydawnictwa UW, Warszawa.

Zając J. (2012), Unia Europejska wobec Arabskiej Wiosny, „Krakowskie Studia Międzynarodowe”, nr 1 (IX).

Zięba R. (2012), International Roles of the European Union, „Rocznik Integracji Europejskiej”, nr 6. 
Zięba R. (2014), Traktatowe uwarunkowania polityki zagranicznej Unii Europejskiej: między politykq wspólnq a interesami państw członkowskich, w: Unia Europejska w regionie śródziemnomorskim: między politykq wspólnq a interesami państw członkowskich, red. J. Zając, Wydawnictwo WDiNP, Warszawa.

\section{Streszczenie}

Unia Europejska odgrywa na arenie międzynarodowej wiele ról, a jednym z priorytetowych kierunków w jej polityce zagranicznej jest region śródziemnomorski. Od połowy lat 90. XX wieku UE stara się odgrywać jednocześnie kilka ról wobec państw w nim położonych. Najważniejszymi z nich są role: aktywnego aktora w rozwiązywaniu konfliktu arabsko-izraelskiego; promotora środków budowy zaufania, partnerstwa, bezpieczeństwa i rozbrojenia; promotora reform rynkowych i zrównoważonego rozwoju; propagatora demokracji i praw człowieka oraz dialogu międzykulturowego.

Efektywność ról międzynarodowych, analizowana na przykładzie unijnej polityki śródziemnomorskiej, jest jednak niska, ze względu na konflikt między rolami deklarowanymi, rzeczywistymi i oczekiwanymi. W konsekwencji region śródziemnomorski nie został przekształcony w obszar pokoju, stabilności, dobrobytu i porozumienia międzykulturowego, co od 1995 roku było deklarowanym przez Unię Europejską celem.

Słowa kluczowe: Unia Europejska, teoria ról, wspólna polityka zagran iczna i bezpieczeństwa UE

\section{The efficiency of international roles played by the $\mathrm{EU}$}

\section{Summary}

The European Union acts in numerous capacities on the international arena, and one of its priorities in foreign policy involves the Mediterranean. Since the mid-1990s, the EU has been trying to play several roles in its relations with countries in this region, the most significant being: an active participant in solving the Arab-Israeli conflict; a promoter of measures to build trust, partnership, security and disarmament; a promoter of market reforms and sustainable development; an advocate of democracy and human rights as well as cross-cultural dialogue.

Assessed on the basis of its Mediterranean policy, the efficiency of the EU's international roles, however, is poor, on account of the conflict between the roles the EU declares to be playing, and its actual and expected roles. As a consequence, the Mediterranean has not transformed into the area of peace, stability, welfare and cross-cultural understanding which has been declared as the EU's objective since 1995.

Key words: European Union, theory of fields, EU foreign policy 
